\title{
Functional Foods from Soybean Oil Deodorizer Distillate using Candida Rugosa and Candida Antarctica lipases
}

\author{
SUMIT NANDI $^{1}$ and GAUTAM MISRA ${ }^{2}$
}

${ }^{1}$ Department of Basic Science and Humanities (Chemistry), Narula Institute of Technology, Agarpara, Kolkata-700109, West Bengal, India

${ }^{2}$ Department of Chemical Technology, University of Calcutta 92, A.P.C. Road, Kolkata - 700009, West Bengal, India

sumitnandi5@gmail.com

Received 20 October 2018 / Accepted 25 November 2018

\begin{abstract}
Functional foods containing sterols and tocopherols create significant attention and find extensive applications in food, cosmetic and pharmaceutical industries in the last few decades. Functional foods not only provide basic nutrition but can also prevent diseases and ensure good health and longevity. In the present study, functional food like sterols and tocopherols concentrate (STC) is prepared from cheap raw material like soybean oil deodoriser distillate (SODD) which is an important by product of vegetable oil refining industries. Initially, SODD is hydrolysed with enzyme Amano-30 (a crude lipase from Candida rugosa) in the presence of water for $8 \mathrm{~h}$ at a certain temperature. The hydrolysed SODD is esterified with excess butanol in the presence of enzyme NS 40013 (Candida antartica, a non-specific immobilized lipase) for $5 \mathrm{~h}$. The esterified SODD is then distilled in molecular distillation unit at a very low pressure and a moderate high temperature. The distilled product contains mainly butyl ester and a very little amount of unsaponifiable matters. Residue fraction contains mainly unsaponifiable matters where higher amounts of tocopherols and sterols are present. This residue fraction may be considered as STC which is utilised as functional foods in the food sector.
\end{abstract}

Keywords: Soybean oil deodoriser distillate, Amano-30, NS 40013, Molecular distillation

\section{Introduction}

Functional foods refers to be those whole, fortified, enriched or enhanced foods that provide health benefits beyond the provision of essential nutrients (e.g., vitamins and minerals), when they are consumed at a certain levels on a regular basis ${ }^{1}$. The National Academy of Sciences' Food and Nutrition Board defined functional foods as "any modified food or food ingredient that may provide a health benefit beyond the traditional nutrients it contains". The International Life Sciences Institute defines them as "foods that, by virtue of the presence of physiologically active components, provide a health benefit beyond basic nutrition". 
The American Dietetic Association defined functional foods as foods that are "whole, fortified, enriched, or enhanced," but more importantly, states that such foods must be consumed as "part of a varied diet on a regular basis, at effective levels" for consumers to reap their potential health benefits. Functional foods play a significant role for the last few decades throughout the world due to rapid technological changes in food science, an enhancing population, the rapid rise in health care costs and changing pattern of food habits ${ }^{2}$.

$\mathrm{DD}$ is an excellent source in this respect as it contains valuable products like phytosterols, tocopherols, sterols and hydrocarbons (mainly squalene), which can be recovered and isolated as food additives ${ }^{3-5}$. Different DDs or fatty acid distillates are used for this purpose like soybean, canola and sunflower ${ }^{6,7}$, palm $^{8-10}$, rice bran oil ${ }^{11}$ etc. SODD has been considered as an important source for the preparation of functional foods such as STC. Different chemical as well as biochemical methods have been applied by researchers for the preparation of functional foods using DDs or SODDs.

Khatoon, Raja Rajan and Gopala Krishna ${ }^{12}$ made a detailed study about physicochemical characteristics and composition of Indian SODD and also recovered phytosterols. Nagao et al., ${ }^{13}$ tried to improve purification technology of sterols and tocopherols from SODD. Present authors also identified a bioprocess technology for the preparation of functional foods from SODD with neutral glycerides containing sterols, tocopherols and hydrocarbons ${ }^{14}$. Lin and Koseoglu ${ }^{15}$ studied about the separation of sterols from DD by crystallization method. Buczenko et al., ${ }^{16}$ also tried to extract tocopherols from the SODD with liquefied petroleum gas. Yang et al., ${ }^{17}$ recovered phytosterols from waste residue of SODD by using bioprocess technology. In another work, sterols were isolated from sunflower oil DD by Carmona et al. ${ }^{18}$ They ${ }^{19}$ also developed another method for phytosterol recovery from DDs. But little study has been made for the enzymatic preparation of STC from SODD using molecular distillation approach. So, in the present study, a bioprocess technology indicating biohydrolysis and bioesterification followed by molecular distillation has been developed for the preparation of STC using enzymes Amano-30 and NS 40013 from SODD. The experimental study contributed good quality STC from SODD utilized as functional foods.

\section{Experimental}

SODD was collected from Sethia Oil Mill, Burdwan, West Bengal, India. Butanol (A.R.) was purchased from E. Merck (India) Pvt. Limited. The lipase NS 40013 (Candida antartica, a non-specific immobilized lipase) was a kind gift of Novozymes, South Asia Pvt. Ltd., Bangalore, India. Lipase AY Amano 30, crude lipase from Candida rugosa with activity $<30000$ units/g, was a gift of AMANO ENZYME, Inc., Nagoya, Japan. Except otherwise specified all other chemicals used were A.R. Grade.

SODD $(100 \mathrm{~g})$ was taken in a $500 \mathrm{~mL}$ Stoppard Erlenmeyer flask and water $(60 \%$ by weight of neutral glycerides) containing lipase powder (5.0\% 'Amano' 30) was added. The reaction mixture was magnetically stirred with a 1 inch Teflon coated stir bar at $35 \pm 2{ }^{\circ} \mathrm{C}$ in a controlled bath for $8 \mathrm{~h}$. After $8 \mathrm{~h}$ of reaction, the hydrolysis was complete and the oil layer and the water layer containing enzyme and glycerol were separated by centrifugation. After that, the oil layer i.e. hydrolysed SODD was taken in a round bottom flask along with butanol (100\% excess) for esterification. The mixture was then stirred by a magnetic stirrer at $60 \pm 2{ }^{0} \mathrm{C}$ for $5 \mathrm{~h}$ using $5 \%$ (by weight of substrates) lipase catalyst (NS 40013). After that, the esterified SODD was filtered for removing the enzyme and was kept for molecular distillation. In both the cases, reaction was monitored by estimating the free fatty acids in the reaction mixture withdrawn periodically. 
The esterified SODD was distilled in a molecular distillation unit (Model MS-300, SIBATA Scientific Co. Ltd., Japan). It was a falling film type apparatus and was provided with a rotating wiper that continuously rubbed the falling film on the evaporating surface. Distillation process was carried out at $160 \pm 2{ }^{\circ} \mathrm{C}$ and a pressure of $10 \mathrm{Pascal}$ for $1 \mathrm{~h}$ to get the distillate. Residual fraction contains $95.6 \%$ unsaponifiable matters where sterols and tocopherols are predominating and were identified by HPLC technique.

\section{Results and Discussion}

Table 1 shows the analytical characteristics and fatty acid composition of SODD. It contains about $72.3 \pm 1.45 \%$ FFA, $15.7 \pm 0.89 \%$ unsaponifiable matters containing tocopherols $(5.5 \pm 0.07 \%)$, sterols $(6.1 \pm 0.11 \%)$ and hydrocarbons $(3.9 \pm 0.07 \%), 10.2 \pm 0.58 \%$ neutral glycerides. Regarding fatty acid composition, Table 1 shows that SODD contains much higher amount of unsaturated fatty acid $(\sim 79.6 \%)$ than saturated fatty acids $(\sim 19.5 \%)$. Among unsaturated fatty acids, it contains $27.8 \pm 0.93 \%$ oleic acid, $48.7 \pm 1.02 \%$ linoleic acid and small amount of linolenic acid. Regarding saturated part, it contains $15.7 \pm 0.36 \%$ palmitic acid and $3.8 \pm 0.09 \%$ stearic acid.

The neutral glycerides present in the SODD were hydrolysed by 'Amano' 30 lipase as shown in Figure 1. Initially, the degree of hydrolysis was very rapid and it was almost completed $(99.13 \%)$ after $8 \mathrm{~h}$ of reaction as depicted in Figure 1. Initial high rate of hydrolysis is due to the fact that the complex formation between glyceride molecules and active sites of enzymes is rapid and thus breakage rate is fast. So within 3-4 hours, a higher conversion has been achieved.

Table 1. Analytical characteristics and fatty acid composition of SODD

\begin{tabular}{cccccc}
\hline Component & $\begin{array}{c}\text { Amount, } \\
\% \mathrm{w} / \mathrm{w}\end{array}$ & Component & $\begin{array}{c}\text { Amount, } \\
\% \mathrm{w} / \mathrm{w}\end{array}$ & Component & $\begin{array}{c}\text { Amount, } \\
\% \mathrm{w} / \mathrm{w}\end{array}$ \\
\hline FFA (Total) & $72.3 \pm 1.45$ & Neu. Glycerides & $10.2 \pm 0.58$ & Unsap. Matters & $15.7 \pm 0.89$ \\
Palmitic acid & $15.7 \pm 0.36$ & MAG & $1.7 \pm 0.61$ & Tocopherols & $5.5 \pm 0.07$ \\
Stearic acid & $3.8 \pm 0.09$ & DAG & $3.6 \pm 0.12$ & Sterols & $6.1 \pm 0.11$ \\
Oleic acid & $27.8 \pm 0.93$ & TAG & $4.8 \pm 0.45$ & Hydrocarbons & $3.9 \pm 0.07$ \\
Linoleic acid & $48.7 \pm 1.02$ & & & & \\
Linolenic acid & $3.1 \pm 0.06$ & & & & \\
\hline
\end{tabular}

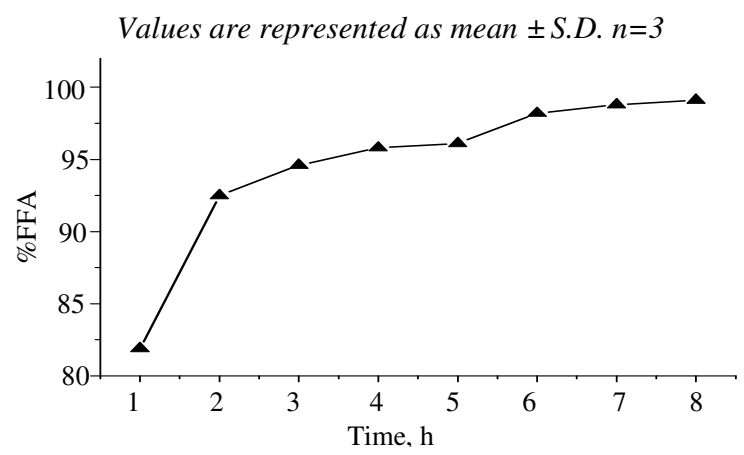

Figure 1. Biohydrolysis of SODD

(Enzyme: Amano-30(5\%), Temperature-35 $\pm 2^{\circ} \mathrm{C}$, Water-60\% of neutral glycerides (w/w))

The hydrolyzed SODD was then esterified with butanol (100\% excess) in presence of NS40013 enzyme. Rate of esterification reaction is very fast initially as depicted in Figure 2. 
It is clear from Figure 2 that within $1 \mathrm{~h}$, nearly $80 \%$ esterification is complete and within $5 \mathrm{~h}$, the esterification reaction is almost $100 \%$ complete.

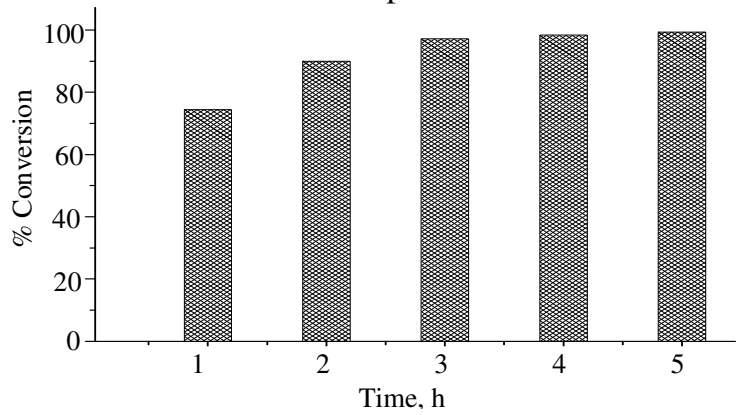

Figure 2. Bioesterification of hydrolysed SODD with butanol (Enzyme used: NS 40013 (5\%), Temperature- $60 \pm 2{ }^{0} \mathrm{C}$, Butanol-100\% excess $\left.(\mathrm{w} / \mathrm{w})\right)$

After bioesterification, the esterified SODD was distilled in molecular distillation apparatus to concentrate sterols and tocopherols. Distillation process was carried out at $160 \pm 2^{\circ} \mathrm{C}$ and a pressure of 10 Pascal for $1 \mathrm{~h}$ where $86.3 \pm 1.05 \%$ distillate was separated and the residual fraction was $12.7 \pm 0.29 \%$. Butyl ester $(94.4 \pm 0.87 \%)$ was the main component in the distillate along with very small amount of unsaponifiable matters. The residual fraction (STC) contains $95.6 \pm 1.11 \%$ unsaponifiable matters where $42.9 \pm 0.71 \%$ sterols and $30.5 \pm 0.67 \%$ tocopherols were identified. Others materials in the residue fraction contains mainly hydrocarbons. Yield and composition of distillate and residue are given in Table 2.

Table 2. Yield and composition of the fractions obtained by molecular distillation

\begin{tabular}{lll}
\hline \multicolumn{1}{c}{ Component } & Distillate $(\% \mathrm{w} / \mathrm{w})$ & Residue $(\% \mathrm{w} / \mathrm{w})$ \\
\hline Yield & $86.3 \pm 1.05$ & $12.7 \pm 0.29$ \\
Butyl ester & $94.4 \pm 0.87$ & - \\
Unsaponifiable matters & $1.1 \pm 0.03$ & $95.6 \pm 1.11$ \\
Tocopherols & - & $30.5 \pm 0.67$ \\
Sterols & - & $42.9 \pm 0.71$ \\
Others & 0.8 & $22.2 \pm 0.19$ \\
\hline
\end{tabular}

Values are represented as mean \pm S.D. $n=3$

\section{Conclusion}

Combined microbial lipase technology offers an excellent way to concentrate sterols and tocopherols from a cheap raw material like soybean oil deodoriser distillate. Enzymatic method of isolation is preferred method than chemical catalytic process in producing better quality product which can be utilized in commercial purposes. Recycling of enzyme can be applied for cost minimization of these bioprocess technology through molecular distillation approach. So biohydrolysis and bioesterification processes along with the application of molecular distillation in a separation methodology is a novel technology for isolation of not only sterols and tocopherols but also other valuable products from by products of oil industries.

\section{Acknowledgement}

Our sincere thanks to University Grants Commission (UGC) for financial support for carrying out this research work. (Sanction No. F. PSW-254/15-16 (ERO). 


\section{References}

1. Clare M H, The Journal of Nutrition, 2002, 132(12), 3772-3781; DOI:10.1093/jn/132.12.3772

2. Olaiya C O, Soetan K O and Esan A M, African Journal of Food Science, 2016, 10(10), 185-193; DOI:10.5897/AJFS2015.1402

3. Sherazi S T H, Mahesar S A and Sirajuddin, J Oleo Sci., 2016, 65(12), 957-966; DOI:10.5650/jos.ess 16125

4. Buczenko G M, de Oliveira J S and von Meien O F, European J Lipid Sci Technol., 2003, 105(11), 668-671; DOI:10.1002/ejlt.200300843

5. Czuppon T, Kemeny Z, Kovari E and Recseg K, "Process for recovery of plant sterols from by-product of vegetable oil refining”, WO2004000979, 2003.

6. Naz S, Sherazi S T H, Talpur F N, Kara H, Sirajuddin and Khaskheli, Pol J Food Nutr Sci., 2014, 64(2), 115-120; DOI:10.2478/pjfns-2013-0008

7. Carmona M A, Jiménez C, Jiménez-Sanchidrián C, Peña F and Ruiz J R, J Food Eng., 2010, 101(2), 210-213; DOI:10.1016/j.jfoodeng.2010.07.004

8. Kamboh M A, Chang A S, Wan Ibrahim W A, Sanagi M M, Mahesar S A, Sirajuddin and Sherazi S T H, RSC Adv., 2015, 5, 50591-50596; DOI:10.1039/C5RA06987D

9. Estiasih T, Ahmadi K, Widyaningsih T D, Maligan J M, Mubarok A Z, Zubaidah E, Mukhlisiyyah J and Puspitasari R, Adv J Food Sci Tech., 2013, 5, 1153-1159.

10. Top A G M, Lipid Technol., 2010, 22(1), 11-13; DOI:10.1002/lite.200900070

11. Nandi S, Gangopadhyay S and Ghosh S, J Oleo Science, 2008, 57(11), 599-603; DOI:10.5650/jos.57.599

12. Khatoon S, Raja Rajan R and Gopala Krishna A, J American Oil Chem Soc., 2010, 87(3), 321-326; DOI:10.1007/s11746-009-1499-8

13. Nagao T, Kobayashi T, Hirota Y, Kitano M, Kishimoto N, Fujita T, Watanabe Y and Shimada Y, J Molecular Catalysis B:Enzymatic, 2005, 37(1-6), 56-62; DOI:10.1016/j.molcatb.2005.09.005

14. Nandi S, Bhattacharyya R and Ghosh T K, Int J Res Appl Sci Engg Tech., 2017, 5(XI), 825-829.

15. Lin K M and Koseoglu S S, J Food Lip., 2003, 10(2), 107-127; DOI:10.1111/j.17454522.2003.tb00009.x

16. Buczenko G M, de Oliveira J S and von Meien O F, Eur J Lip Sci Tech, 2003, 105(11), 668-671; DOI:10.1002/ejlt.200300843

17. Yang H, Yan F, Wu D, Huo M. Li J, Cao Y and Jiang Y, Bioresour Technol., 2010, 101(5), 1471-1476; DOI:10.1016/j.biortech.2009.09.019

18. Carmona M A, Jiménez C, Jiménez-Sanchidrián C, Peña F and Ruiz J R, J Food Eng., 2010, 101(2), 210-213; DOI:10.1016/j.jfoodeng.2010.07.004

19. Carmona M A, Jiménez C, Jiménez-Sanchidrián C and Ruiz J R, Curr Nutr Food Sci., 2015, 11, 4-10. 